\title{
AUTOCITAÇÃO FICTIVA EM PORTUGUÊS EUROPEU E BRASILEIRO ${ }^{1}$
}

\author{
Luiz Fernando Matos ROCHA*
}

- RESUMO:A Autocitação Fictiva (ROCHA, 2004, 2006) é um tipo discursivo de fictividade por meio do qual seus conceptualizadores impõem uma perspectiva avaliativa ao discurso direto. Por meio de um cenário não verídico de reportação discursiva, o agente ilocutório remete-se a um cenário prévio e suposto de fala, com propósito de permitir acesso mental ao cenário verídico de pensamento. O objetivo deste artigo é a descrição e análise da autocitação fictiva e sua co-extensão factiva em corpora orais de Português Europeu e Brasileiro, a partir da construção (EU) DISSE/FALEI X-ORACIONAL. Utilizam-se como dados o corpus C-ORALROM Português (BACELAR DO NASCIMENTO et al., 2005) e o corpus C-ORAL Brasil (RASO; MELLO, 2010, 2012), bem como os corpora CINTIL (2011), NURC (2011) e um reality show. Os resultados apontam para contrastes conceptuais e diafásicos entre usos de "disse" e "falei" nas variedades nacionais, uma vez que o verbo "falar" não costuma ser usado para introduzir discurso reportado em PE e que certos frames interacionais são propícios ao surgimento de autocitação fictiva, como o reality show. Contudo, a fictividade afeta a autocitação em ambas variedades, mapeada por pistas que incluem reportação monológica, co-texto epistêmico, escaneamento mental, incongruência dêitica e atos de fala como promessa.

- PALAVRAS-CHAVE:Autocitação. Fictividade. Linguística Cognitiva. Linguística de Corpus.

\section{Autocitação Fictiva: aspectos preliminares}

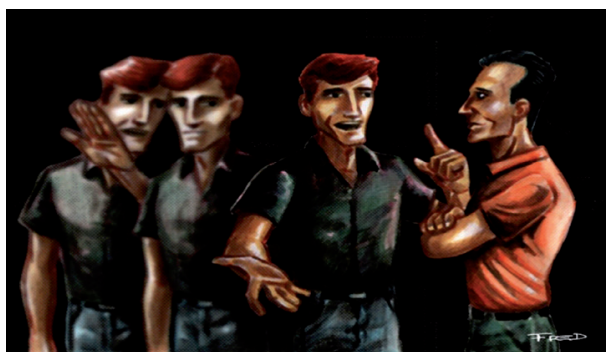

(FCARTUNES, 2011)

* UFJF - Universidade Federal de Juiz de Fora - Faculdade de Letras. Juiz de Fora - MG - Brasil. 36036-900 - luiz. rocha@uff.edu.br

1 Este produto intelectual é parte da investigação resultante do projeto de pesquisa Construções gramaticais de conversa fictiva: convergências entre frames cognitivos e interacionais (bolsista da CAPES - Processo: BEX 4084/10-1), desenvolvido durante cumprimento de estágio pós-doutoral sob supervisão do Prof. Dr. Augusto Soares da Silva (2010-2011), em regime de colaboração com o Centro de Estudos Filosóficos e Humanísticos da Universidade Católica Portuguesa (CEFH-UCP), Centro Regional de Braga (Portugal), no âmbito da linha de investigação Estudos Linguísticos e Literários e do projeto Linguística Cognitiva do Português: semântica e gramática. 
O discurso direto (DD) é tradicionalmente reconhecido como um dos moldes de discurso reportado cuja finalidade é reportar, integral e literalmente, a escrita, a fala ou o pensamento de alguém em prévia ocasião, sendo que esse alguém pode ser o próprio enunciador do discurso. Tomado de modo isolado, o exemplo que segue emblematiza o discurso direto em forma de autocitação:

(1) Eu disse: "Ai, meu Deus, o que é que eu vou fazer? E agora?"

Considerando-se a definição de DD acima disposta, a sentença complexa (1) admitiria pelo menos três interpretações básicas, polissemicamente ancoradas no verbo dicendi prototípico "disse": o sujeito "Eu", da oração principal, (i) escreveu, (ii) proferiu ou (iii) apenas pensou o discurso encaixado "Ai, meu Deus, o que é que eu vou fazer? E agora?", em uma circunstância anterior. Pode-se, então, postular dois grupos mínimos para abarcar a polissemia de "disse" em (1): primeiro, os significados de "disse" como "escrevi" e "proferi" como uma autocitação factiva (AFac), visto que sinalizam o ato prévio e factivo de expressão verbal, respectivamente na escrita e na fala; e, segundo, o significado de "disse" como "pensei", "considerei" ou "avaliei", que não sugere ato de expressão verbal prévia, diferenciando-se do grupo anterior pelo seu caráter sobretudo epistêmico, apresentando comportamento de verbo sentiendi (de sentir). Estabelece-se assim o que aqui se chama de Autocitação Fictiva (AFic), ou seja, a possibilidade de se conceptualizar um cenário em que o falante afirma ter dito algo que sugere apenas pensamento e não necessariamente fala.

Nesse sentido, a pergunta deste artigo pode ser sumarizada da seguinte forma: que implicações cognitivas, discursivas e interacionais validam produção e interpretação de verbos como "disse" apenas como "pensei" ou "avaliei", uma vez que o verbo "dizer" não evoca apenas pensamento, mas sobretudo fala? A resposta a essa questão pode começar a ser desenvolvida com base na hipótese inédita de que o discurso direto em forma de autocitação apresenta instâncias fictivas ou virtuais (AFic) de seus tipos comunicativos, como diametralmente opostas, mas contíguas, às suas instâncias factivas (AFac). Ou seja, um molde direto de discurso reportado também pode se apresentar como uma forma fictiva ou virtual de evocar discursos apenas mentalmente construídos.

Argumenta-se que ocorre um desemparelhamento (mismatch) entre forma e significado, os quais são "incongruentes com respeito a padrões mais gerais de correspondência na língua" (FRANCIS; MICHAELIS, 2003, p.2). Uma vez que

Segundo o Dicionário Priberam da Língua Portuguesa (2010), o verbete "dizer" apresenta como primeira entrada a acepção "exprimir por meio de palavra, por escrito ou por sinais (ex.: dizer olá)". Ainda: o uso do verbo "dizer" no sentido de "escrever" é comum em casos de reparo a alguma coisa anteriormente mencionada (ex.: "Qual o chavão, digo... a religião ideal pra você?" (OFİCIO..., 2011). 
uma AFic é um padrão não canônico proveniente do padrão canônico de discurso direto, pode ser que se configure como uma consequência direta de processos de gramaticalização e, principalmente, como um produto do padrão geral de fictividade, segundo o qual "[...] duas representações discrepantes - embora não exclusivamente - estão em desacordo com relação a alguma dimensão, representando pólos opostos dessa dimensão." (TALMY, 1996, p.212), quais sejam: factiva (concebida pelo conceptualizador como real) e fictiva (concebida pelo conceptualizador como irreal). Por essas razões, não é o caso de se aplicar aqui a noção clássica de verificação de condições de verdade, pois, para este estudo, é irrelevante saber se o falante proferiu ou não o discurso relatado, mas importa saber se a representação mimética desse discurso reportado é avaliada pelos conceptualizadores como mais ou menos factiva, como mais ou menos fictiva.

Em contraponto à AFac, cuja referência direta ou descrição da "realidade" é ponto de afastamento, a AFic é um tipo comunicativo de fictividade discursiva, mais restrito ao tipo textual narrativo de caráter oral, em que o frame da construção de discurso direto, em formato de autocitação, é interacionalmente acionado, porém parcialmente vinculado ao referente pretendido. Por meio de um cenário não verídico de reportação discursiva, o agente locutório remete-se a um cenário prévio e suposto de fala, com propósito efetivo de permitir acesso mental ao cenário verídico de pensamento. A AFic não se configura como um tipo de citação direta, ou mesmo paráfrase, de enunciados realmente proferidos em trocas comunicativas ou inventadas, sendo, na verdade, avaliada como objetivamente atual; ${ }^{3}$ no entanto, subjetivamente virtual. Respectivamente, isso significa dizer que a AFic é presentificada como situação efetiva, mas veiculada por meio de um processo abstrato e indireto de subjetificação. Tanto o Português Europeu (PE) quanto o Brasileiro (PB) apresentam usos de AFic com o verbo "dizer", como se pode ver a seguir:

(2) Eu quando peguei no sapato um estava direito tinha lá ficado no sítio mas ela (cachorra) com o outro é que ela hhh fez a dança toda e eu quando vi aquilo disse ai meu deus o que é que eu vou fazer e agora olha eu fiz os sapatos uns sapatos azul-marinho e agora o que é. (Português Europeu, PE - Corpus CINTIL) ${ }^{4}$

\footnotetext{
Opto por traduzir o termo actual (oposto de "virtual" em Langacker $(1987,1999,2008)$ ) por "atual", sobretudo pela analogia viável entre o conceito de "fictividade" (TALMY, 1996; LANGACKER, 1987) e o de "virtualização" de Pierre Lévy. Segundo Lévy (2009), virtual se opõe ao atual por se tratar de um complexo problemático que invoca uma atualização, que é a invenção ou criação de uma solução potencialmente exigida pelo virtual, como a árvore que está virtualmente na semente, cujo "problema" é brotar. Ou ainda: o meio virtual da ultrassonografia que permite o interior passar ao exterior permanecendo no interior, como na descoberta do sexo do bebê. Por meio do virtual, acessamos o atual, elemento vigente ou presente.

4 Corpus do português europeu desenvolvido na Universidade de Lisboa (Portugal) pelo Grupo REPORT, do CLUL - Centro de Linguística da Universidade de Lisboa, em cooperação com o Grupo NLX-Natural Language and Speech, do Departamento de Informática. Embora ele tenha sido aproveitado para um levantamento
} 
(3) A primeira vez que eu o vi, eu devia ter doze pra treze anos e ele cinco anos mais velho que eu, eu olhei e disse: eu vou namorar esse cara. Não sei como não, mas eu vou namorar esse cara. Aí alguns, alguns anos depois, acho que uns dois anos depois, ele mudou-se pra perto da minha casa. (Português Brasileiro, $\mathrm{PB}$ - Corpus NURC) $)^{5}$

Considerando a princípio seus contextos comunicativos de uso, nos quais são percebidas a ausência co-textual de enquadre de reportação dialógica bem como o caráter valorativo ou apreciativo de ambas as situações, as AFics em negrito de (2) e (3) representam indiretividade e incompatibilidade entre expressão linguística e situação referida. Pode-se conceber que o que se afirma que foi dito não foi dito, mas apenas pensado. Ou seja, tais instâncias fictivas exigem um processamento mental virtual, embora sejam situacionalmente motivadas e com base no conhecimento de mundo.

É certo que a semântica e a sintaxe dessas instâncias em negrito não bloqueiam por completo seu entendimento factivo. Contudo, sem dúvida alguma, são construções discursivamente fictivas, introduzidas em contextos narrativos como eventos dinâmicos, mas que de fato são de caráter mais estático. "Dizer" sugere aprioristicamente dinamismo; não obstante, nos enunciados acima, esse dinamismo da ação enunciativa passa de ativo a contemplativo, de factivo a fictivo. Por isso, como em (2) e (3), "disse" aciona um estado mental que conecta virtualmente os interlocutores a uma proposição de caráter avaliativo, apreciativo ou valorativo, não directamente factiva.

Nas construções de autocitação fictiva, ocorre citação virtual de pensamento; a unidade discursiva relatada não é autossuficiente, pois se trata de uma oração encaixada a um construtor de espaço mental dicendi/sentiendi; a oração encaixada pode ser conceptualizada como não factiva via construtor virtual de espaço mental; seu tempo verbal e dêixis, por vezes, se relacionam ao da cláusulamatriz. Enfim, são elementos que complexificam o entendimento da possibilidade de a autocitação ser analisada como instância virtual de discurso direto. Mas como o próprio nome diz (discurso reportado) e como o enquadre linguístico é tão importante quanto o conteúdo enquadrado em se tratando de Linguística Cognitiva, o desempate é mesmo de cunho discursivo, o que faz convergir frames cognitivos com frames interacionais.

inicial de usos de AFic e AFac em PE, utilizamos no corpo deste texto apenas alguns exemplos extraídos diretamente do CINTIL, para efeito de ilustração. Entretanto, pelo fato de que boa parte desse corpus foi absorvido pelo Projeto C-ORAL-ROM (CRESTI; MONEGLIA, 2005), então ele está de certa forma presente na computação geral de ocorrências constantes da seção "Análise dos resultados".

5 Corpus do português brasileiro desenvolvido na Universidade Federal do Rio de Janeiro, no âmbito do Projeto Norma Linguística Urbana Culta - RJ. 
A partir da exposição preliminar do objeto que se pretende analisar empiricamente, este artigo se organiza daqui por diante da seguinte forma: (i) seção acerca das bases metodológicas que nortearam a tarefa de levantar instâncias reais de fala espontânea das autocitações fictiva e factiva em corpora de PE e PB, eletronicamente tratados e balanceados; esta seguida por outra (ii) seção acerca da análise quantitativa e qualitativa dos dados, a qual enfatiza a importância de se submeterem categorias estabelecidas por teóricos cognitivistas ao crivo dos estudos empíricos; (iii) nas considerações finais, sumarizam-se as dimensões epistêmicas e pragmáticas do objeto de investigação com o propósito de demonstrar que o plano discursivo é capaz de fornecer pistas claras para a diferenciação entre autocitação fictiva e factiva.

\section{Bases metodológicas para respostas empíricas}

Com o propósito de contrastar qualitativa e quantitativamente o fenômeno da fictividade e factividade na autocitação entre duas variedades nacionais do Português (Europeu e Brasileiro), elegemos como base de dados primordial duas das vertentes internacionais do Projeto C-ORAL-ROM (CRESTI; MONEGLIA, 2005), ${ }^{6}$ este fundado no âmbito dos Fifth Framework Program of the European Union e Information Society Technology Program, com sede no Laboratório LABLITA da Universidade de Florença (2011) (Itália). Ambos os corpora apresentam bases similares de arquitetura, favorecendo pareamentos mais precisos entre estudos comparativos entre PE e PB. No caso desta investigação, análises de ordem quantitativa e qualitativa se restringem às transcrições dos textos orais, bem como a alguns metadados que identificam participantes, data, local, situação, etc.

Os corpora são os seguintes:

1) Corpus do Português Europeu compilado pelo Grupo de Linguística de Corpus do Centro de Linguística da Universidade de Lisboa (CLUL) (2011) (BACELAR DO NASCIMENTO et al., 2005). O C-ORAL-ROM (CRESTI; MONEGLIA, 2005) compreende 152 textos que cobrem um período de 30 anos (1970-2002), totalizando cerca de 30 horas de gravação e de 317.916 palavras gráficas transcritas;

2) Corpus do Português Brasileiro compilado por pesquisadores vinculados ao Núcleo de Estudos em Linguagem, Cognição e Cultura (NELC), ao Laboratório de Estudos Empíricos e Experimentais da Linguagem (LEEL) e ao Grupo Interfaces Linguagem, Cognição e Cultura (Incógnito), os quais estão sediados na Faculdade

\footnotetext{
"A principal meta do projeto C-ORAL-ROM é fornecer um conjunto comparável de corpora de língua falada espontânea das principais línguas românicas, nomeadamente Francês, Italiano, Português e Espanhol." (CRESTI; MONEGLIA, 2005, p.1).
} 
de Letras da Universidade Federal de Minas Gerais (RASO; MELLO, 2010, 2012). Com base na diatopia do estado de Minas Gerais (basicamente a região metropolitana da capital Belo Horizonte), o corpus prevê pelo menos 200 textos e 300.000 palavras, divididos em uma metade formal (a ser implementada) e uma metade informal (já utilizada nesta pesquisa). De acordo com informações do site do C-ORAL-BRASIL (UFMG, 2011), a metade informal (coletada entre os anos 2007 e 2010) se divide em um domínio privado/familiar (80\%) e um domínio público (20\%). Cada domínio se divide em monólogos (1/3), diálogos (1/3) e conversações $(1 / 3) .{ }^{7}$ Submetido à ferramenta TextSTAT, esse grupo de dados apresenta 13.243 types e 233.934 tokens.

Como se poderá notar, por vezes, lanço mão ainda do banco de dados Big Brother Brasil (2002), ${ }^{8}$ por mim coletado e transcrito para minha tese de doutorado (ROCHA, 2004) e cuja estrutura não está adequada ao padrão C-ORAL. Se fosse submetido a esse padrão, o banco de dados Big Brother Brasil poderia ser enquadrado como pertencente à classe formal, do tipo mídia e subtipo reality show. Segundo informações obtidas por meio da ferramenta TextSTAT, ele apresenta 3.851 types e 43.319 tokens, correspondentes a quatro horas e meia de gravações ininterruptas do programa. A decisão por inserir esse material se relaciona ao fato de que é possível endossar a natureza colostrucional do padrão (EU) DISSE/ FALEI X-ORACIONAL no pareamento com frames interacionais específicos, o que também é permitido pelos corpora C-ORAL em virtude da disponibilização dos metadados.

É preciso mencionar ainda o levantamento de AFics e AFacs feito junto ao corpus do NURC-RJ (Projeto da Norma Urbana Oral Culta do Rio de Janeiro - Brasil), que reúne entrevistas gravadas entre as décadas de 1970 e 1990, perfazendo um total de 1.500 horas, com informantes com nível superior completo, nascidos no Rio de Janeiro e filhos de pais preferencialmente cariocas. Ainda de acordo com informações do site, esse material representa o desempenho linguístico de falantes de ambos os sexos, distribuídos em três faixas etárias - 25 a 35 anos, 36 a 55, e 56 anos em diante - gravados em três situações distintas: 1) aulas e conferências; 2) diálogos informais; 3) entrevistas. $\mathrm{O}$ arquivo sonoro da fala do Rio de Janeiro abrange um total de 394 entrevistas com 493 informantes, sendo $238(60,4 \%)$ do tipo diálogo entre informante e documentador, 99 (29,1\%) do tipo diálogo entre dois informantes e 57 (14,4\%) de elocuções formais.

Os metadados da parte informal do corpus encontram-se em fase de finalização e não puderam ser aproveitados nesta investigação.

8 Reality show produzido pela Rede Globo de Televisão (2002) e exibido sem interrupções por um dos canais Sky (TV por assinatura via satélite). 


\section{Métodos e justificativas: "Falei-e-disse"9}

Em linhas gerais, os métodos e as justificativas partem da axiomatização de dois ditos sentenciosos produzidos por uma aldeã portuguesa durante um almoço com sua família, em 2010. Após enumerar uma grande quantidade de árduas tarefas exigidas por seu cotidiano no campo, foi-lhe perguntado se haveria outras mais, ao que ela responde: "Também não podes ter tudo!". Certo tempo depois, falando sobre um dos pratos servidos durante a refeição, galinha assada, e para deixar os convivas à vontade, institui localmente um provérbio: "Galinha é feita para comer com a mão!". Se fosse ensopada (em PB) ou estufada (em PE), talvez o procedimento fosse outro e não pudéssemos abrir mão do garfo e da faca. No entanto, podíamos comer com a mão, já sabendo que não se pode ter tudo. Ora, os preceitos também-não-podes-ter-tudo e galinha-é-feita-para-comer-com-amão têm a ver, análoga e respectivamente, com:

(i) os limites de quantificação de dados desta investigação, uma vez que computar e analisar o emparelhamento de determinadas construções com grandes quantidades de material discursivo, contemplando frames cognitivos e interacionais, demanda esforços cuja medida é o possível de cada pesquisador, em determinado momento. Como afirmam Waugh et al. (2006, p.122, tradução nossa), "[...] enquanto mais ênfase [em relação aos demais capítulos do livro] em linguística de corpus tem sido sobre imensos corpora (às vezes consistindo de milhões de palavras), aqui focaremos em corpora menores com comunidades de fala bem definidas em eventos de fala bem definidos.";

(ii) os procedimentos adotados para se investigar o objeto, visto que ele se apresenta de forma peculiarmente perspectivizada. No caso da analogia com a galinha assada, mesmo podendo-se dispor de garfo e faca como ferramentas acessórias (nesta investigação, eletrônicas), para se destrinçar a comida (nesta investigação, discurso direto fictivo e factivo), a opção pelo manual, dadas as especiais condições do objeto, não poderia ser descartada.

Então, vamos aos meus limites de "tudo" e dos procedimentos para destrinçar a "galinha". Tomou-se como ponto de partida o rastreamento nos corpora de contextos de ocorrência dos lexemas "disse" e "falei" em virtude de poderem ser intuitiva e usualmente considerados prototípicos de discurso direto (especificamente, de autocitação), como instâncias específicas dos lemas dicendi DIZER e FALAR — isso embora o "falar" não seja comum em português europeu como introdutor de discurso relatado. No entanto, trata-se de uma informação importante para o estabelecimento de contraste entre variedades nacionais do

\footnotetext{
Expressão idiomática típica do $\mathrm{PB}$, de caráter reiterativo, cujo significado é o de sentenciar convictamente uma proposição como conclusiva e praticamente inquestionável. Por exemplo: Falei e disse: "A saúde entra pela boca". (MURFY, 2011).
} 
Português, no sentido de verificar se essa diferença implica distinções culturais e conceptuais.

A opção pela primeira pessoa do singular do pretérito perfeito do indicativo diz respeito:

(i) a dêixis de primeira pessoa do singular favorável à busca de autocitações, como exemplares de reportação discursiva propícios à localização da fictividade em discurso direto. Casos de autocitação em primeira pessoa do plural foram descartados por se partir do princípio nocional de que se um grupo de mais de um sujeito produz, em coro, certo enunciado reportado, cairia por terra a possibilidade do uso de "dizer" exclusivamente como "pensar";

(ii) ao entendimento de que o discurso reportado (AFac ou AFic) normalmente remete a um espaço passado de caráter perfectivo, haja vista sua própria definição e a escolha de um particípio passado ("reportado") para linguisticamente enquadrálo. No entanto, é possivel admitir usos de AFic com verbos no imperfeito (ex.: "Eu dizia (pensava): 'ai meu Deus!"') e no presente histórico (ex.: "Eu digo (penso): 'ai meu São Geraldo!'”);

(iii) quanto ao modo indicativo, temos em conta que ele tende mais à expressão da factividade cujo contraponto factual é a base para a virtualização das construções fictivas, ou seja, a indiretividade da fictividade depende da diretividade factiva; em outros termos, diretividade remete ao processo de referenciação mais verídico das entidades e situações, enquanto a indiretividade, ao menos verídico. O modo subjuntivo é mais propenso à localização de discurso reportado em contextos hipotéticos, ou seja, mais objetivamente irreais, o que não é nosso objetivo.

A decisão por restringir formas de busca de fictividade na autocitação, em dados orais, com dêixis de primeira pessoa do singular associada ao pretérito perfeito do indicativo obtém maior delimitação quando seus exemplares são separados em duas "prateleiras" paradigmáticas básicas — ambas esquematicamente ancoradas na construção semiaberta (EU) DISSE/FALEI X-ORACIONAL:

(i) (EU) DISSE/FALEI (PROFERI) X-ORACIONAL, de caráter factivo;

(ii) (EU) DISSE/FALEI (PENSEI) X-ORACIONAL, de caráter fictivo.

Pode-se notar desde já que se trata de uma escolha proposital por construções "despidas" de sintagmas "direcionais" (ex.: "lhe", "para ela", "com João", etc.), os quais indicariam de imediato os destinatários e, por conseguinte, o caráter semanticamente factivo do discurso direto. A escolha se alinha à busca de fatores externos à estrutura argumental (GOLDBERG, 1995) que podem dar conta da factividade ou da fictividade das construções gramático-discursivas de autocitação. Em parte, a localização dessas construções nos corpora se deu 
via ferramentas eletrônicas (concordanciadores Contextes e TextSTAT), mas a separação nas duas prateleiras de tendências foi feita manualmente, dada a importância de se contemplar o material circunvizinho a essas instâncias, para posterior separação em autocitação fictiva e factiva.

\section{Análise dos resultados}

Justificadas as escolhas, partimos para a quantificação dos dados, para posterior contraste entre os resultados extraídos do C-ORAL-ROM Português e do C-ORAL Brasil. Quaisquer conclusões a partir desse procedimento dizem respeito exclusivamente a esses corpora e não a generalizações acerca de ambas variedades nacionais do português como um todo. Conforme anunciado, assume-se, em PE, de modo geral, que o verbo "falar" não perfila subestrutura na base dicendi. Essa constatação advém de consultas formais e informais feitas a nativos de PE e, em parte, da investigação de frequência em corpora. Certamente, trata-se de uma informação datada, uma vez que os corpora consultados têm limites temporais, bem como a intuição dos nativos diz respeito ao momento que circunscreveu o desenrolar desta investigação.

$\mathrm{Na}$ variedade europeia do corpus, a tarefa de introduzir a voz de outrem, considerando dados de fala espontânea, caberia sobretudo ao verbo "dizer". Pelo menos no tocante à sua frequência no corpus C-ORAL-ROM Português, as formas de seu lema somam 1.983. Considerando todas as 317.916 palavras transcritas do corpus, perfazem um total de 0,62\%. Como esta investigação se limita à autocitação na primeira pessoa do pretérito perfeito do indicativo, buscouse inicialmente a forma "disse", que apareceu 230 vezes, sendo que apenas 50 corresponderam ao padrão (EU) DISSE X-ORACIONAL (44 AFacs e seis AFics).

As seis AFics compreendem conversas entre colegas, cientes da presença do gravador, sendo a maioria com pesquisador presente. No que diz respeito ao tipo de metadados classe, as ocorrências se distribuem em (i) informal, familiar/privado, monólogo (3); (ii) formal, mídia, entrevista (1); (iii) formal, formal em contexto natural, conferência (1); (iv) informal, público, conversação (1). A pouca quantidade de dados nesse corpus em relação à AFic não é condição suficiente para garantir que esse tipo de autocitação não pertença ao inventário de construções gramáticodiscursivas de PE. Por outro lado, o mesmo corpus apresenta apenas 21 usos de "falei". A maior parte das ocorrências associa o verbo a sintagmas preposicionais, como "falei em", "falei de", "falei com", "falei a(o)".

Manipulado por meio da ferramenta TextSTAT, o corpus C-ORAL Brasil apresentou números bem distintos em relação às ocorrências de "disse" e "falei", bem como em relação a AFics e AFacs. O vocábulo "disse" aparece apenas 22 
vezes, sendo que apenas dois instanciam AFac, e não há casos de AFic com esse verbo. Já o "falei" ocorre 351 vezes, sendo 153 usos em contexto de AFac e 68 em AFic.

Com auxílio da ferramenta TextSTAT, buscaram-se também no corpus NURC-RJ ocorrências do item lexical "disse". Os resultados foram bem distintos dos encontrados no corpus C-ORAL Brasil. O TextSTAT devolveu para o corpus NURC-RJ 812 tokens "disse" (em 1a $2^{\text {a }}$ e $3^{\text {a }}$ Pessoas do Singular do Pretérito Perfeito do Indicativo), sendo 318 somente de $1^{\text {a }}$ PSPPI. Dos 318, 169 estão inseridos em expressões conformativas, discurso indireto, construções transitivas diretas com objeto resumitivo, construções transitivas (bi)indiretas, construções transitivas direta e indireta. O restante, 149 , diz respeito ao padrão focalizado (EU) DISSE X-ORACIONAL (A Y), subdividido em:

(i) (EU) DISSE X-ORACIONAL - 90 (factivos)

(ii) (EU) DISSE X-ORACIONAL A Y - 30 (factivos)

(iii) (EU) DISSE (PENSEI) X-ORACIONAL - 29 (fictivos)

Em contrapartida, no banco de dados Big Brother Brasil (ROCHA, 2004), "disse" aparece seis vezes: cinco na terceira pessoa e um na primeira. Este único caso de autocitação é factivo. Não há casos de AFics com "disse" no banco de dados. No entanto, "falei" ocorre 69 vezes, sendo 43 casos (62,3\%) em contextos de AFics e 26 em AFacs (37,7\%).

Em relação à autocitação fictiva, os números apresentados por cada corpus sinalizariam contrastes marcantes entre variedades nacionais do Português bem como contrastes diafásicos e diatópicos entre os dados de fala do C-ORAL Brasil e do NURC-RJ e o banco de dados Big Brother Brasil, salvaguardadas as devidas distinções de arquitetura entre corpus e banco de dados.

O que preliminarmente chama atenção no cruzamento entre C-ORAL Brasil e NURC-RJ é a quantidade de usos gerais de "disse" no primeiro (22) e a quantidade de usos do mesmo token no segundo (812), independentemente de critérios de factividade e fictividade, bem como de pessoas discursivas. Seria o caso de hipotetizar em favor de variação diatópica entre variedades carioca e mineira de PB. Entretanto, deve ser contemplada a arquitetura de ambos os corpora e sobretudo a diferença entre eles em relação a procedimentos teóricometodológicos. Mesmo admitindo-se tais considerações, não seria o caso de dispensar o fato de que em PB o verbo "disse" também pode integrar construções de autocitação fictiva, como vimos no exemplo (3).

Longe de banalizar os esforços de elaboração de cada corpora, o que se defende aqui é que se formos nos basear apenas nos dados do C-ORAL Brasil, 
poderíamos postular uma irrisória quantidade de usos de "disse" em PB e, por conseguinte, cair na falácia de que o verbo está em fase de desuso ou de que em Portugal se "diz", enquanto, no Brasil, se "fala". Não se trata disso, uma vez que o mesmo poderia ser dito em relação ao número de ocorrências de "disse" fictivo no C-ORAL-ROM Português, que se restringe a seis casos apenas. Estamos lidando com corpora específicos e suas interdições. Embora sejam imensos, são corpora e não a totalidade da língua.

Entretanto, considerando as não interdições, os corpora C-ORAL Brasil e C-ORAL-ROM Português apontam para preferências colostrucionais ${ }^{10}$ específicas na integração de verbo com a autocitação, o que talvez se estenderia aos demais moldes de discurso reportado. Talvez pudéssemos afirmar que, em termos de fala espontânea no domínio exclusivo desses corpora, PE sinaliza preferência pelo verbo "dizer" como dicendi; enquanto PB, pelo "falar". De fato, há que se tomar cautela com essa generalização dada a diatopia e a variação diastrática específica de ambos os corpora. Por outro lado, é o que ocorre em termos de autocitação, fictiva ou factiva, no recorte desta pesquisa. Seria o caso de perguntar: o que subjaz a essas escolhas considerando o estudo de propriedades sociais, culturais e conceptuais desse tipo específico de variação pluricêntrica? Como verbos, que processos específicos "dizer" e "falar" perfilam na função dicendi/sentiendi?

Em certa medida, a etimologia dos verbos "dizer" e "falar" endossa a natureza construcional nas perspectivizações conceptuais distintas de AFac e AFic, pois aponta para a fragilidade do conceito de sinonímia no que diz respeito à integração do significado do verbo com o todo da construção discursiva de autocitação. "Dizer" advém do verbo latino dico, is, ere, dixi, dictum, cuja proto-raiz grega, deik, a mesma de dêixis, significa mostrar ou apontar. Assim, etimologicamente "dizer" tem o sentido de mostrar pela palavra. Por outro lado, "falar" é proveniente do verbo latino fabulo, as, are, significando contar, narrar, tagarelar ou inventar. Contemporaneamente, podem ser considerados verbos sinônimos, ou seja, significam exprimir por meio de palavras. Entretanto, a extensão de preferências por determinados itens lexicais para ocorrer em slots construcionais particulares (collocations) ${ }^{11}$ faz com que eles atuem, pelo menos semanticamente, de modo distinto nas instâncias de ocorrência.

"Dizer" só é igual a "falar" quando se admite a existência de sinônimos perfeitos, o que acionaria uma concepção de cognição desengajada (LANGACKER, 2008), segundo a qual grande parte de nossa atividade cognitiva é desassociada da experiência corpórea imediata, pois faz uso de meios fundamentais para

10 A hipótese colostrucional de Stefanowitsch e Gries (2003, 2008) envolve essencialmente a identificação da força de associação entre uma determinada construção e um item lexical.

11 De acordo com Saeed (2003, p.60), collocation refere-se à tendência de as palavras repetidamente ocorrerem juntas. 
transcendê-la, como a memória, a projeção de futuro com base na observação do presente e sobretudo os modelos de abstração. Assim, sinonímia pode ser considerada uma abstração, sem se considerarem graus de instanciação colostrucionalmente estabelecidos, pois, desta forma, "dizer" e "falar" passam a disparar significados distintos, por fazerem parte de construals distintos.

Contudo, faz-se necessário avaliar isso em termos empíricos e sincrônicos. Comecemos pela expressão "falei e disse", 12 que, em PE, equivaleria semanticamente a "tenho dito". ${ }^{13}$ Trata-se de um ponto de partida emblemático em virtude do fato de que ambos, "falei" (V1) e "disse" (V2), estão em coordenação aditiva num mesmo composto lexical. Em PB, como unidade lemática construcional, "falei e disse" é um marcador discursivo cuja operação argumentativa, para além da semântica lexical, assinala pragmaticamente uma conclusão enfática. Contudo, sem dispensarmos plenamente a leitura composicional, pois o todo também está relacionado às partes, observamos uma reiteração semântica interna que se inicia por "falei" e não por "disse", sem remetermos de forma alguma a um pleonasmo. A fixação dessa ordem específica para a formação do idioma "falei e disse" não é aleatória. Por que a coordenação entre os dois verbos não é inversa, como "disse e falei"?

Sua concatenação estrutural sugere que o V2 reitera V1 arrematando sua interpretação. Essa arrematação com V2 sugere que "disse" perspectiviza conceptualmente algo diferente de V1. É preciso assumir, então, a hipótese de que "disse" perfilaria mais um processo pontual e incisivo de demonstração de conteúdos pelas palavras, o que é endossado pela expressão "tenho dito", em PE. Diferentemente disso, "falar" perfilaria mais um processo geral de verbalização, que remete a capacidades e habilidades de produção de fala. Todavia, ambos podem assumir a função superordenada dicendi/sentiendi, dependendo das frequências de usos em variedades nacionais do Português, bem como de variações diafásicas em termos intralinguísticos.

Podemos ilustrar o perfilamento de ambos os processos verbais com outro dito, que emite o seguinte juízo de valor: "Falamos muito, dizemos pouco", ${ }^{14}$ segundo o qual "falamos" suscitaria uma profusão contínua, excessiva e abundante de oralidade, enquanto "dizemos" focaliza a enunciação de conteúdos pontualmente relevantes em termos de pensamentos e sentimentos. Admitindo-se uma suposta inversão em "Dizemos muito, falamos pouco" ou "Falamos pouco, dizemos muito", a conotação encaminhada pelo perfilamento verbal integrado à construção aponta para a paráfrase de que mesmo falando pouco dizemos muito, ou seja, mesmo não

12 Expressão que intitula o blog do brasileiro jjDourado (FALEI E DISSE..., 2011).

13 Expressão que intitula o blog do português António Lopes da Costa (2011).

14 Amigos de Jesus (2011). 
fazendo uso da profusão contínua, excessiva e abundante de oralidade, somos capazes de dizer com poucas palavras coisas tomadas como relevantes.

Tendo em vista o corpus C-ORAL e os perfis de cada processo verbal em foco, o fato de PE sinalizar preferência pelo verbo "dizer" como dicendi e PB eleger o "falar" para essa função, pelo menos em termos de autocitação, não tem a ver com a pervasividade dos casos de AFic em ambas as variedades. Muito pelo contrário, o fenômeno ocorre tanto em PE quanto em PB, mas com verbos dicendi/sentiendi específicos.

Retomemos, então, a hipótese de que o discurso direto em forma de autocitação apresenta instâncias virtuais (fictivas) de seus tipos comunicativos como diametralmente opostas, mas contíguas, às suas instâncias atuais ou efetivas (factivas). Testando-a com base nos dados extraídos dos corpora e do banco de dados mencionados, o que primeiramente deve ser destacado é a questão do enquadre de reportação dialógica ou monológica na tomada de decisão pela leitura fictiva ou factiva da autocitação, sendo ambas predominantemente características do tipo textual narrativo. Além disso, no cenário de reportação, o endereçado ouve ou escuta uma avaliação em caso de AFic; entretanto, ouve ou escuta um diálogo reportado quando se trata de AFac. Dessa forma, a tendência geral é a seguinte: quando a construção de autocitação está imersa na reportação de diálogos, a opção pela interpretação factiva é mais clara. A simples inserção do discurso de outrem no jogo de vozes sinaliza trocas conversacionais prévias entre participantes reportados, como podemos verificar a seguir:

(4)

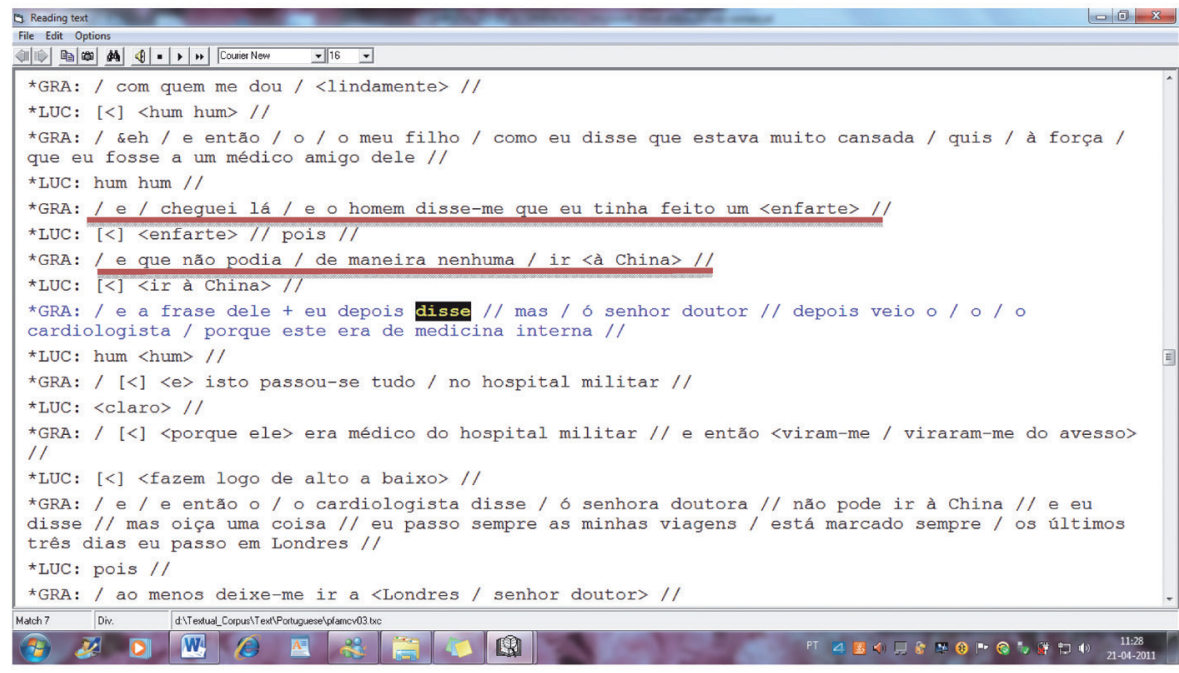

(C-ORAL-ROM PORTUGUÊS) 
Em (4), no terceiro turno de GRA, "e o homem disse-me que" constrói um espaço mental de discurso indireto via dicendi + complementizador ("que"), o qual localmente empreende uma marca propícia à reportação dialógica, abarcando como argumento externo uma terceira pessoa ("homem") e um sintagma direcional ("me"). Dessa forma, aciona-se claramente a perspectiva do outro, mesmo que de forma branda, para que o enunciador anuncie posteriormente a sua própria perspectiva. Note ainda que o encaixe "eu tinha feito um enfarte e que não podia de maneira nenhuma ir à China" referencia o evento diretamente. O quinto turno de GRA, "eu depois disse mas ó senhor doutor", arremata a interpretação factiva da autocitação com o uso de "depois" com valor de sequência temporal de eventos e com o encaixe imediato da conjunção "mas", que retoma o espaço-base aberto por "e o homem disse-me que", estabelecendo uma operação de caráter contra-argumentativo; com o vocativo interjectivo "ó senhor doutor", que não se configura como instância genérica, mas factiva. Disparado o frame cognitivo de comunicação discursiva, nota-se claramente que o ambiente discursivo é mais favorável a atos de fala como pedido, instrução, aconselhamento e sugestão, vinculando-se à face de competência, aquela em que o falante reivindica para si o respeito e a aprovação de ter suas habilidades reconhecidas. Tais considerações também se aplicam a (5), em que temos um exemplo de AFac em PB, que apresenta suas especificidades:

(5) então eu nũ sei // eu tomei anestesia antes de sentir dor / ele falou / não precisa de sentir dor // começou dar contração já vou te dar anestesia // dor é coisa do passado / nũ sei o quê // beleza // o Bernardo / aí ele falou assim / Regina / do jeito que eu te conheço / e sei que cê é tranquila / eu falei / cê pode ir pro hospital sim // que até cê sair de Contagem e chegar aqui no Otaviano Neves // porque no Otaviano Neves que es nasceram // falei / ah / então assim / doutor Fernando / eu vou / e peço o médico de plantão / pra e' olhar // se ele achar que tá / já na hora / aí eu ligo pro sior / sior vai po Otaviano Neves // sior mora lá perto / tal // não / beleza // então faz isso // que e' tava dormindo // aí na hora que eu chego no Otaviano Neves / tá bem sentadinho // e' lá na recepção me esperando // aí eu falei assim / ah / o sior veio // e ocê acha / que eu nũ te conheço // cê é tranquila.

(C-ORAL BRASIL)

As sequências negritadas de autocitação em (5) também estão completamente imersas em ambiente de reportação dialógico, o que, em geral, propicia sua conceptualização factiva. Tanto "ele falou / não precisa de sentir dor // começou dar contração já vou te dar anestesia // dor é coisa do passado / nũ sei o quê" quanto "o Bernardo / aí ele falou assim / Regina / do jeito que eu te conheço / e sei que cê é tranquila" circunscrevem uma conversação reportada, criando sucessivos espaços mentais dicendi, que conferem a marcação de perspectiva alheia, anterior 
à perspectiva de autocitação. Dessa vez, todos os casos de discurso reportado em (5), em molde direto, evidenciam maior força na perspectiva do falante reportado (SANDERS; REDEKER, 1996), ao contrário do molde indireto. De certa forma, isso endossa a natureza factiva das autocitações da falante de (5), porque a voz do outro ou a própria voz reportadas diretamente ganham dinamicidade conceptual, em vez de contornos contemplativos em torno do cenário descrito. Os participantes reportados são mais ativos em termos de veiculação dos discursos.

Além disso, outras pistas internas à autocitação contribuem para sua leitura factiva: em "eu falei / cê pode ir pro hospital sim", a dêixis de segunda pessoa "cê" (embora formalmente "cê", redução de "você", possa ser considerado de terceira) se alinha ao espaço passado aberto pelo construtor "eu falei", harmonizando deiticamente a destinação do discurso de uma primeira pessoa para uma segunda em um momento temporalmente não discrepante. Na sequência "falei / ah / então assim / doutor Fernando", o elemento interjetivo "ah" integrado ao marcador de retomada de espaço anteriormente aberto, ou seja, de discurso reportado, e ao vocativo não genérico "doutor Fernando" evoca a factividade no interior da fala encaixada.

Externamente à autocitação em si, como exemplo final do excerto (5), temos: "aí eu falei assim / ah / o sior veio // e ocê acha / que eu nũ te conheço // cê é tranquila". O marcador discurso "aí" e advérbio "assim" — com seu valor semântico dêitico básico (COSTA, 1997) correspondente a "desse modo", "dessa maneira" ou "desse jeito" - remetem ao que foi factivamente dito. Por isso, contribuem para o aparecimento de sequências AFacs. Isoladamente, tais expressões dêiticas não garantem se a interpretação é factiva ou fictiva, pois ambas são passíveis de ocorrer em ambientes de AFic, ou seja, dependem do contexto em que estão ancoradas para endossar uma leitura ou outra.

Finalmente, partimos para as ocorrências de AFics em PE e PB. O entorno linguístico à AFic é similar em ambas as variedades. Isso quer dizer que as pistas co-textuais e contextuais são semelhantes na determinação fictiva da autocitação, contribuindo para o acionamento do frame cognitivo de avaliação, geralmente emparelhado com atos de fala como promessa, planejamento, avaliação e apreciação, e relacionado com a reivindicação de face de amizade, aquela em que o sujeito discursivo almeja ser socialmente incluído, em busca de solidariedade.

No exemplo (6) de AFic em PE, logo abaixo, há três participantes:AMA (mulher, 40-50 anos, pesquisadora, interveniente, lisboeta), MAR (mulher, 40-50 anos, ensino médio, do Porto) e XYZ (homem, interveniente), que conversam sobre cães. Com gravador não escondido e pesquisador presente, a interação se enquadra na classe informal, familiar/privada, monólogo, cuja gravação foi feita nos idos de 1970. MAR relata o fato de que teve um de seus sapatos roído por seu cão: 
(6)

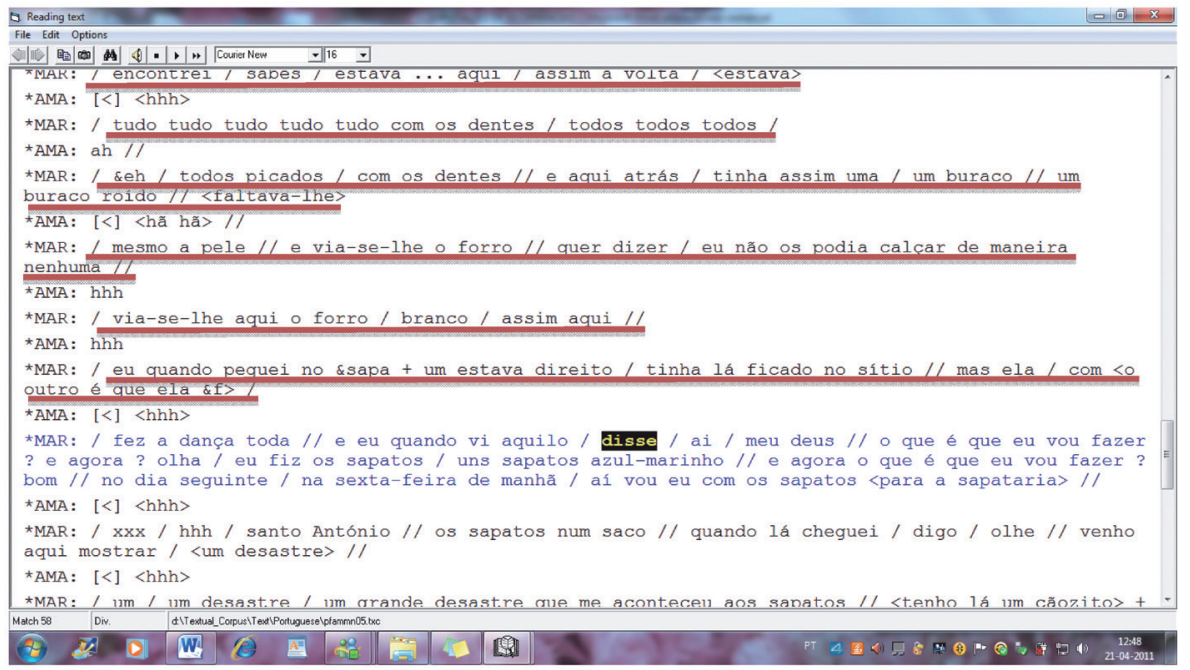

(C-ORAL-ROM PORTUGUÊS)

O primeiro ponto a se destacar são as falas de MAR, produtora do enunciado AFic, cujo verbo "disse" vem assinalado em tarja preta. Note que o enquadre de reportação monológica é evidente (trechos sublinhados), embora no cenário atual haja intervenções de AMA, outra participante, que basicamente se limitam a "hhh", que simbolizam elementos paralinguísticos ou não linguísticos. Não há reportação dialógica co-textual, e a narrativa desemboca na autocitação de caráter fictivo, subordinada a um construtor de espaço mental temporal ("e eu quando vi aquilo"), que prepara o terreno linguístico para o anúncio de uma apreciação. A oração encaixada "ai/ meu Deus// o que é que eu vou fazer? e agora?" recorre ao elemento interjetivo "ai", que endossa a incompatibilidade entre forma e significado de "disse", conceptualizado como "pensei". Interjeições seriam comuns apenas à expressão da oralidade, mas são também capazes de evocar conteúdos estritamente epistêmicos. Além disso, o vocativo "meu Deus" suscita uma interlocução com uma entidade sem referente no mundo, o que se relaciona à baixa resolução ou granularidade de AFic, seguida por duas perguntas retóricas de caráter fictivo, que apontam para uma projeção temporal futura, embora deiticamente ancoradas no espaço passado da enunciação relatada. "Como o futuro a Deus pertence", em se tratando de pareamento de discurso com dados de cultura em PE (também em PB), tal projeção ganha um caráter imponderável e imprevisível; portanto, desengajado, pelo menos no "por-enquanto" do fluxo discursivo. Tais elementos diluem quaisquer ambientes factivos de enunciação, permitindo que o valor epistêmico de "disse" se convalide como "pensei", "apreciei", "considerei" ou "conclui", incompatível com seu uso 
meramente reportativo ou reconstrutivo de diálogos. Por isso, AFics apresentam, em geral, valor de conclusão apreciativa acerca de um fato relatado e não de um relato de vozes de outrem, sendo detectadas pelo conjunto de pistas diluídas discursivamente.

Examinemos outro caso de AFic em PE, que endossa as considerações em torno de (6). Trata-se de uma outra interação, cujos metadados se distinguem da seguinte maneira: dois participantes, JOA (mulher, acima de 60 anos, graduada, aposentada, entrevistada e lisboeta) e NUN (homem, 18 a 25 anos, estudante universitário, entrevistador e lisboeta); conversa entre colegas num café no ano de 2001, com gravador não escondido e pesquisador participante. O tópico é a educação de JOA, e a classe, informal, familiar/privada, monólogo. O exemplo (7) de AFic é produzido por JOA:

(7)

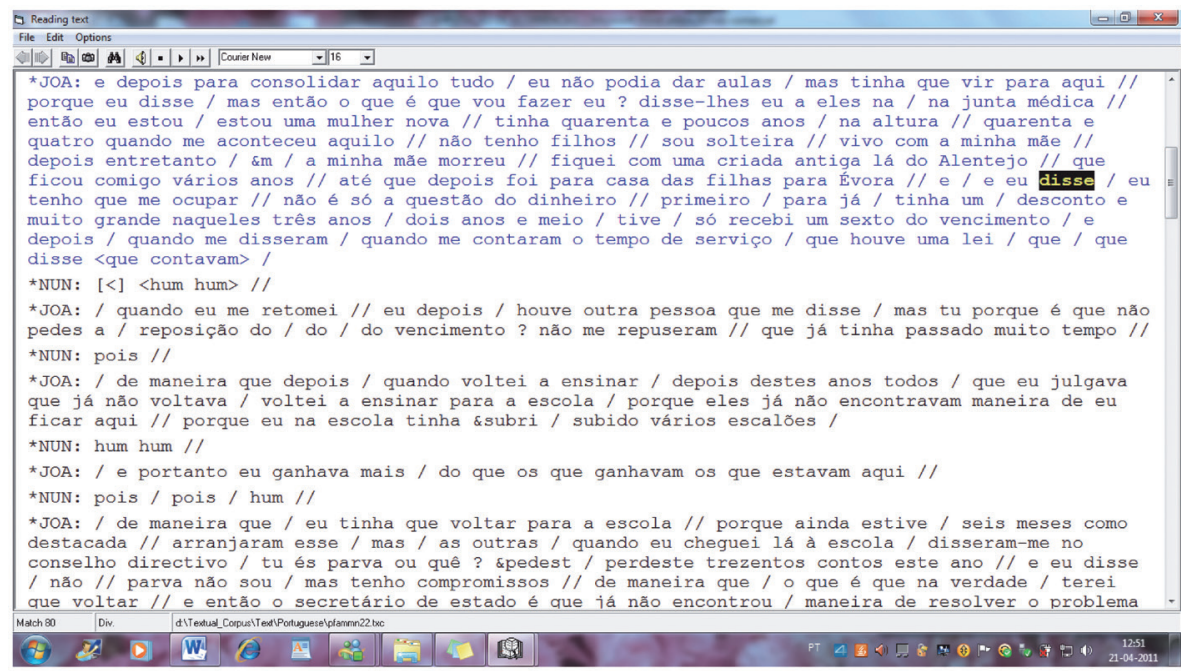

Em (7), o enunciado "e eu disse/ eu tenho que me ocupar / não é só a questão do dinheiro" é passível de ser enquadrado como AFic, embora haja menção a outros sujeitos reportados no fluxo inicial do discurso ("disse-lhes eu a eles / na junta médica"). Para tanto, deve-se levar em consideração o fato de que, por si só, o conteúdo proposicional de "e eu disse/ eu tenho que me ocupar/ não é só a questão do dinheiro" não apresenta status epistêmico, mas se tomado como promessa, na enunciação, passa a evocar cenário fictivo ou virtual (LANGACKER, 2008). ${ }^{15}$

15 O autor afirma que a fictividade se expressa inclusive na invocação fictiva de um cenário de ato de fala. A proposição de "Eu estarei lá", por exemplo, não codifica promessa por si só, mas, se tomada como enunciado, 
Além disso, é fundamental destacar a ausência de um sintagma "direcional" imediata e localmente amalgamado ao verbo dicendi - "e eu disse (a eles)/ eu tenho que me ocupar/ não é só a questão do dinheiro", o que coloca em cheque a certeza de factividade na reportação discursiva. Essa ausência fortalece ainda mais a possibilidade de interpretação fictiva do referido enunciado quando o enquadre imediato que o antecede, representado pelo trecho "depois entretanto/ \&m / a minha mãe morreu // fiquei com uma criada antiga lá do Alentejo // que ficou comigo vários anos // até que depois foi para casa das filhas para Évora", menciona um tempo posterior ao encontro com a junta médica.

Nessa interação reportada com a junta médica, JOA afirma que vivia com a mãe, mas, em momento discursivo subsequente, enuncia o falecimento da mãe, bem como a partida da criada. Infere-se então que JOA esteja tratando de sua condição solitária, nesse momento. Acrescenta-se a isso a conjunção "e / e" (presente em "e / e eu disse"), que pode ser lida como "e então", expressão de caráter conclusivo que desemboca na tomada de decisão "eu tenho que me ocupar". Isso possibilita a interpretação fictiva, de caráter mais contemplativo e avaliativo, do que reportativo.

Em geral, é comum nos casos de AFic a ausência de tais sintagmas "direcionais". Como o endereçado do pensamento reportado é o próprio falante do cenário de reportação, a autocitação se torna mais fictiva. Entretanto, torna-se fundamental o uso do dicendi/sentiendi para que se estabeleça a discrepância característica da fictividade, pois, no caso, "dizer" está por "pensar", ou mais especificamente, por "avaliar". É como se JOA, em (7), dissesse: "eu avaliei: eu tenho que me ocupar, não é só a questão do dinheiro", mesmo fazendo uso de "disse". Além disso, novamente, percebe-se a projeção futura no encaixe reportado, o que corrobora o caráter epistêmico local de um verbo dicendi/sentiendi, cuja semântica apriorística favoreceria a leitura factiva. No cenário de reportação de (7), há um endereçado: NUN. Além de não fazer parte do cenário reportado, ele se limita a simples consentimentos como "hum hum" e "pois", permitindo o livre fluxo digressivo de JOA.

Entretanto, tais condições não podem ser sempre consideradas sine qua non para delimitação da construção de AFic, pois, como venho defendendo, todas as ocorrências devem ser pontualmente avaliadas e quaisquer generalizações são, por demais, arriscadas. Por isso, insisto que se trata mesmo de um "pântano", permeado de tendências e não de limites categóricos. Mesmo assim, é importante adentrar ainda mais na areia movediça da autocitação fictiva, tendo como corda de salvação outras pistas linguísticas fundamentais. Quero dizer com isso que AFics podem aparecer em contextos de reportação dialógica, como de certa forma foi prenunciado.

passa a assumir essa condição. 
Observemos então os metadados de (8): participantes, MAN (mulher, 25 a 40 anos, pesquisadora, entrevistadora e lisboeta) e JOS (homem, 40 a 50 anos, professor, entrevistador e açoriano); conversa entre colegas num café em 2001, com gravador não escondido e com pesquisador participante; o tópico é tese de doutorado; e a classe, informal, familiar/privado, diálogo. Passemos ao exemplo:

(8)

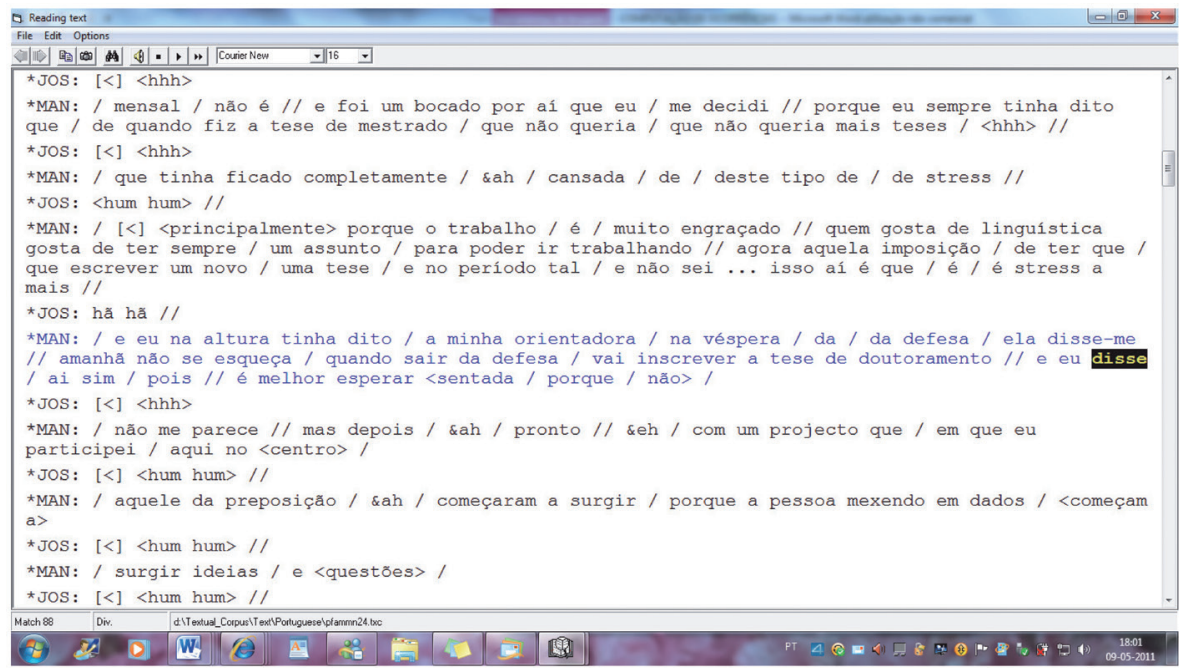

(C-ORAL-ROM PORTUGUÊS)

Em (8), a autocitação prefaciada por "disse", em tarja preta, pode ser considerada um caso fronteiriço entre AFac e AFic. Antes, é preciso mencionar que o participante JOS, na sequência da autocitação, apenas produz "hhh", que, conforme já dito, simboliza elementos paralinguísticos ou não linguísticos, os quais careceriam de verificação prosódica, para se perceber qual seu significado pontual. Entretanto, é certo que ele não demonstra dúvida acerca do caráter factivo ou fictivo da autocitação de MAN.

Outras pistas prosódicas e contextuais são muito relevantes para a discussão de (8). Por exemplo, no meio da sequência "e eu disse/ ai sim/ pois // é melhor esperar <sentada", há duas barras (//). Segundo critérios de tipos de pausas prosódicas do C-ORAL-ROM (CRESTI; MONEGLIA, 2005), trata-se de um símbolo que representa pausa prosódica conclusiva, de valor terminal. Com isso, poderíamos admitir que a AFac se encerraria em "pois //", considerando que há um enquadre de reportação dialógica, cujas participantes são MAN e sua orientadora de mestrado. Assim, "é melhor esperar <sentada" se configuraria como uma unidade enunciativa à parte, admitindo-se que desconhecemos as motivações subjacentes à produção de "//" por MAN. 
Por outro lado, impor uma perspectivação AFic ao enunciado como um todo no fluxo discursivo "e eu disse/ ai sim/ pois // é melhor esperar <sentada" não é completamente implausível, sem desrespeitarmos a informação melódica. Por quê? Mesmo sob o enquadre reportativo dialógico e mesmo com a informação prosódica mencionada, a unidade entoacional "é melhor esperar <sentada/" aciona um ato de fala fictivo e por conta disso faz com que "disse" perfile inclusive "considerei" e não apenas "proferi" (o primeiro encaixe "ai sim/ pois" já apresenta valor de concordância e assentimento). Tratar-se-ia de uma proposição, a princípio, sem status epistêmico, mas como "é melhor esperar <sentada/" é encaixada num contexto específico, evoca ironicamente uma promessa, ou seja, a de sair da defesa de mestrado e logo se inscrever no doutorado. Ainda sob o domínio de um construtor dicendi/sentiendi de espaço mental que a antecede, tal resposta fictiva à orientadora só poderia ser pensada por MAN no cenário prévio a (8), mas não proferida, visto que MAN violaria a máxima de qualidade (GRICE, 1982), provocando constrangimento entre orientanda e orientadora. Por sua vez, o endereçado JOS em (8), professor, supostamente conhecedor da dinâmica das relações político-acadêmicas e de que um enunciado como esse seria um bom motivo para verificação, do tipo "disseste isso a ela?", simplesmente aproveita seu turno para produzir "hhh". Ou seja, isso pode ser entendido como: MAR não disse isso à sua orientadora, mas está sinalizando fictivamente sua divergência em relação ao fato de se inscrever no doutorado após a defesa de mestrado.

Em termos de emparelhamento das AFics com os subcampos por classes de corpora definidas por Cresti e Moneglia (2005), basicamente divididos em formal e informal, é preciso dar relevo ao fato de que as ocorrências desse padrão construcional se dão em ambos os níveis. Um estudo mais aprofundado sobre os tipos e subtipos de classes em nível de relação colostrucional com as AFic e AFac não é propósito pontual desta investigação, dado que os casos de AFic do corpus C-ORAL-ROM Português são poucos e que não dispusemos dos metadados do C-ORAL Brasil. No entanto, é possível sinalizar que as AFics, em PE, se alocam nas classes informal e formal. Os exemplos analisados até o momento pertencem à parte informal dos corpora. Já o (9) pertence à parte formal e apresenta os seguintes metadados: participante (MAR, mulher, 25 a 40 anos, psicóloga, conferencista); a situação é o XIX Colóquio da Associação de Professores Católicos, realizado em 2001, com gravação não escondida e pesquisador não presente; o tópico, desenvolvimento mental e valores religiosos; a classe é formal, formal em contexto natural, conferência. 
(9)

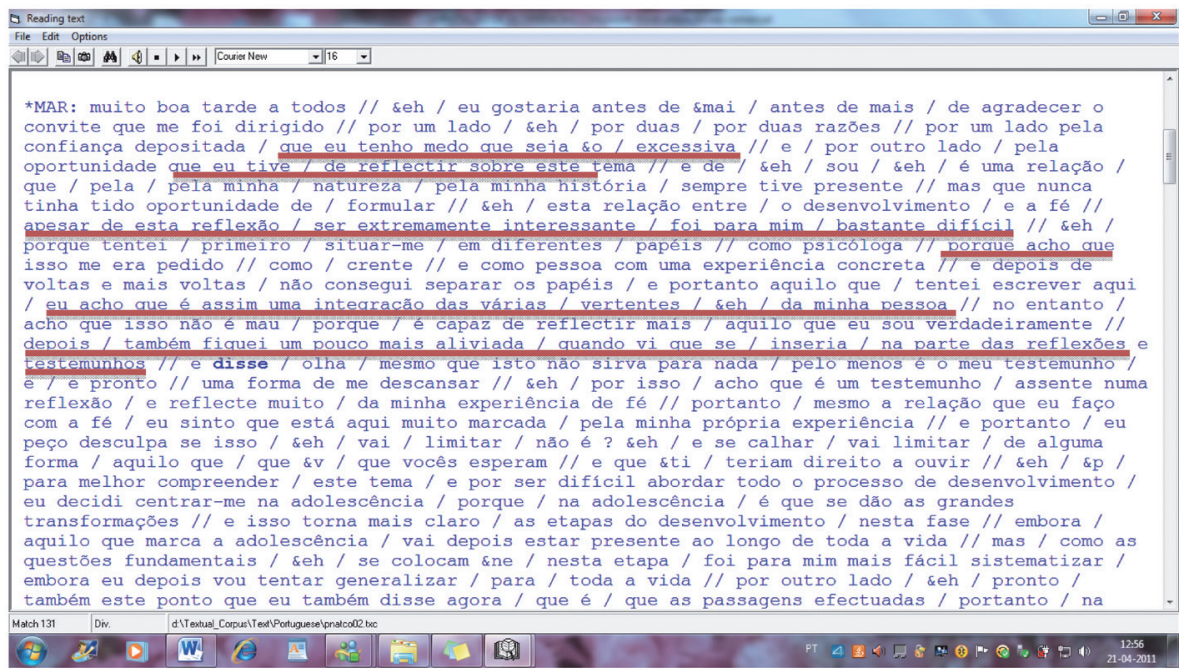

(C-ORAL-ROM PORTUGUÊS)

O excerto (9) é a abertura de uma conferência em que MAR faz uso de AFic num contexto marcadamente subjetivo, permeado de perspectivações conceptuais indicadoras de um envolvimento incisivo do sujeito da conceptualização no perfilamento de aspectos dos objetos de conceptualização. O enquadre apreciativo, subjetivo e epistêmico é ilustrado pelas expressões sublinhadas, antecedendo a AFic "e disse/ olha/ mesmo que isto não sirva para nada / pelo menos é o meu testemunho/ e/ e pronto // uma forma de me descansar". O que se encaixa após "disse" é uma clara demonstração de debate interno relatado. O uso da expressão atencional "olha", autodirecionada, é seguida da construção concessiva encabeçada por "mesmo que", a qual desemboca numa explícita modalização via remoção de barreiras (SWEETSER, 1990) com o uso de "pelo menos", associado à subjetividade máxima de "é meu testemunho". MAR figura como elemento de uma relação conceptualmente geradora de expectativas objetivas, pois ela se insere em um contexto discursivo formal (conferência), mas, por outro lado, migra, pelo menos na abertura de sua fala, para um fluxo discursivo subjetivista. Isso caracterizaria o excerto como instância de um processo geral de subjetificação, inerente às AFics.

Os casos até agora discutidos sugerem que a construção AFic é um todo fictivo e não apenas o verbo dicendi/sentiendi a ela integrado, haja vista as pistas internas e externas à autocitação fictiva. Isso reforça a hipótese colostrucional de que, ao interagir com as construções, sejam elas em quaisquer níveis de complexidade, gramatical ou discursiva, o verbo pode assumir comportamentos 
sintáticos e semânticos multifacetados. No caso desta investigação, por razões metodológicas, a sintaxe da autocitação se encerra em uma fórmula semiaberta específica, mas quando lançamos olhar sobre ela na dimensão dos corpora, os tipos de encaixe variam sobremaneira em termos de dêixis, interjeição, vocativos, etc. Agora, é preciso acionar os dados em PB para que possamos estabelecer sua análise específica de usos de "falei" fictivo e efetuar posteriormente um contraste entre variedades nacionais acerca das discussões até aqui empreendidas.

A hipótese de que o pensamento encaixado na construção AFic se dá por escaneamento mental, e não exclusivamente por movimento conceptual, parece se confirmar tanto para as ocorrências em PE quanto para as em PB. A modalidade fictiva de autocitação se relaciona a um escaneamento mental de um pensamento prévio, pressupondo o crivo ou a contemplação, subjetivos, de determinadas situações e consolidando-se como uma unidade construcional e colostrucional específica na integração entre construtor de espaço mental dicendi/sentiendi e oração encaixada. O exemplo (10) ilustra bem isso:

(10) \&he / fiquei um ano / falei / ah / mas eu fiz isso / pronto // fiz minha \&li [/2] minha licenciatura bem feita // se precisar / bem / mas / queira Deus que eu nunca hei de precisar desse trem // vou / passar no concurso / vou trabalhar nas empresa / vou ser redatora / tradutora / vou mexer com esses negócio // mas nunca dei a sorte // aí / foi a \&p [/3] situação foi ficando difícil / quase um ano formada e sem ganhar dinheiro algum / pá // qual eu falei / \&v [/1] \&v [/1] um dia eu desesperei

\section{/ falei / ô gente / acho que eu tenho que sair aí / ir numa escola aí / deixar meu currículo nas escolas //}

*REN: hum hum //

(C-ORAL BRASIL)

Novamente, podemos estabelecer uma divisão entre os elementos externos e internos à AFic. O co-texto que precede "falei / ô gente / acho que eu tenho que sair aí / ir numa escola aí / deixar meu currículo nas escolas" não é marcadamente de reportação dialógica, mas eminentemente de relato de planejamentos. Diante disso, o enunciador pré-condiciona subjetiva e discursivamente o escaneamento mental sobre a construção de autocitação fictiva de (10), imediatamente antecedida pelo verbo "desesperei", que perfila emoção acentuada. O que sucede ao construtor de espaço mental dicendi/sentiendi "falei" é um encaixe encabeçado pelo interjetivo "ô", que exprime os afetos do ânimo não necessariamente em condições factivas e se ancora no vocativo genérico "gente", desengajado de quaisquer instâncias específicas. A emissão da expressão verbal "acho", em modalidade epistêmica, amalgamada ao restante do encaixe oracional de promessa, também contribui para conferir fictividade à construção como um todo. Boa parte das ocorrências de AFic no corpus C-ORAL Brasil apresenta encaixe relatado em formas de promessas e 
planejamentos, o que mais uma vez corrobora a postulação de Langacker (2008) acerca da invocação fictiva de cenários de ato de fala, ou seja, proposições sem status epistêmico apriorístico, se tomadas como promessa, evocam cenário fictivo.

O exemplo de AFic em (11) ilustra muito bem a relevância do fenômeno da dêixis, especialmente no discurso encaixado, para o estabelecimento da interpretação fictiva da autocitação. Embora haja o prenúncio de reportação dialógica, a emanação fictiva persiste. Acompanhe o fragmento a seguir:

*EDE: <a sua menina / envem aí // <tá grandona / viu > //

*JUL: $<$ tá grande> //

*JUN: <tô tomando remédio yyyy $>$ //

${ }^{*} \mathrm{EDE}:<$ oito anos $>/ /$

*MAR: <sarou / a dor no estômago > //

*JUL: $<$ dez $>/ /$

*LOH: <não / meu estômago / e' / falou que é gastrite / né> //

*EDE: <No' / achei que ea tinha $>$ + <ah / já entendi> //

*MAR: <ah / tá> //

*JUL: <teve um dia que alguém me falou assim / Nossa / cê tá velha / hein / sua menina tá com dez anos / eu falei / velha é ela //

*JUN: <ô gente / tem um remédio tão bom que eu tô tomando yyyy> //

*MAR: <Buscopan $>/ /$

*JUL: que tá com dez ano //

*EDE: <velha é a estrada / <cê nũ falou com ela > //

*JUL: <eu não > //

*JUN: <e' chama é [/1] é [/1] é [/1] é> +

*MAR: <minha mãe / quando tá com dor de estômago / ea toma é Buscopan // toma o Buscopan então / que tira a dor> //

(C-ORAL BRASIL)

A terceira fala de JUL em (11) reporta o seguinte: "teve um dia que alguém me falou assim / Nossa / cê tá velha / hein / sua menina tá com dez anos / eu falei / velha é ela //". A leitura desta fala é reificada conceptualmente como factiva até JUL preencher o espaço mental aberto por "eu falei" com a asserção ofensiva "velha é ela". É importante destacar que a dêixis de terceira pessoa ("ela") é responsável por fictivizar o todo da autocitação, subjetificando-o enfaticamente. Suponha que JUL tivesse rebatido diretamente o que ela própria considerou no episódio narrado uma ofensa por parte desse "alguém", ou seja, "Nossa / cê tá velha / hein / sua menina tá com dez anos /". JUL poderia ter reportado sua resposta desta forma: "eu falei: velha é você". A permuta de "você", de segunda pessoa, por "ela", de terceira, no X-ORACIONAL da autocitação é dêitica e fictivamente emblemática. A dêixis de terceira pessoa "ela" é incompatível e discrepante em relação ao cenário 
pretérito marcado pelos verbos "teve", "falou" e "falei" e à interação entre duas interlocutoras que se tratariam em segunda pessoa, como "você", como é o caso do "alguém", que se utiliza de uma variante desse pronome: "cê tá velha". Tal discrepância, marca primordial de fictividade, é desencadeada apenas por uma pista linguística, que é suficiente para EDE comentar na sequência: "<velha é a estrada / <cê nũ falou com ela> //". E JUL responde: "<eu não> //". Não falou, porque apenas pensou. Pode ser que, nesse trecho, JUL esteja negando apenas que falou "velha é a estrada", mas a sobreposição de vozes não garante isso, visto que JUL pode ainda estar se remetendo ao fato de não ter chamado o "alguém" de velha.

\section{Sumário e conclusões}

Finalmente, podemos estabelecer uma tabela comparativa de tendências entre AFics e AFacs em termos de aspectos semântico-pragmáticos, com base nos dados encontrados nos corpora em PE e PB; e, a partir desse contraste, retomar e focar as dimensões da fictividade aqui postuladas, quais sejam: (i) dimensão epistêmica, ancorada em mecanismos de cognição como frames cognitivos, escaneamentos mentais, extensões metafóricas e metonímicas, etc.; (ii) dimensão pragmática, que agrega frames interacionais, dêixis, atos de fala e trabalhos de face, etc.

A constatação de sua multidimensionalidade só é possível quando estudamos o fenômeno com base em dados reais de fala, os quais fornecem evidências no âmbito cognitivo e interacional de forma a delimitar mais precisamente as tendências que levam à leitura factiva ou fictiva da autocitação. É preciso salientar que cada característica semântico-pragmática disposta separadamente na tabela seguinte não é por si só suficiente para a atribuição de valor fictivo ou factivo à autocitação. Tais tendências atuam simultaneamente, convergindo para o estabelecimento multifacetado da fictividade. Estabelecidas dentro do domínio definido pelo tipo textual narrativo, as dimensões epistêmica e pragmática da AFic estabelecem contiguamente a convergência entre frames cognitivos e interacionais de natureza fictiva, colaborando ao mesmo tempo com a noção de fictividade geral em termos de mapeamento do fenômeno a partir de pistas discursivas extraídas de corpora.

A dimensão epistêmica da AFic comporta tendências específicas para:

(1) a reportação preferencialmente monológica, afeita a contextos digressivos e subjetificadores da enunciação, em que proliferam conteúdos expressivos de emoção, fictivamente perspectivizados; 
(2) o material co-textual epistêmico, o qual favorece colostrucionalmente o encaixe da AFic, à medida que, lançando mão de expressões subjetificantes, como o uso de verbos como "achar", "pensar", "desesperar", etc., torna o ambiente discursivo propício ao entendimento da autocitação como fictiva;

(3) o uso de verbos "disse" (em PE e PB) e "falei" (PB) com o sentido de "pensei" ou "considerei", licenciado pela metáfora PENSAMENTO É FALA ou pela metonímia DIZER/FALAR POR PENSAR (ROCHA, 2006), que desemboca numa integração epistêmica com a construção de autocitação; isso faz com que a função prototípica dicendi (de dizer) desses verbos passe a assumir também um valor sentiendi (de sentir), bem como provoca uma incongruência entre forma e sentido, dado o desemparelhamento entre a forma canônica de autocitação direta e o significado de avaliação da AFic;

(4) a evocação do frame de avaliação, em que o conceptualizador emite um juízo de valor, via autocitação fictiva, acerca de determinada entidade ou situação;

(5) o escaneamento mental, em que o conceptualizar percorre mentalmente um conjunto de alternativas concebidas e arranjadas em determinada ordem, ou seja, no caso de AFic, ele contempla, escaneando, uma situação prévia, imobilizada no passado, a partir do crivo valorativo da autocitação fictiva;

(6) a presença de vocativos genéricos, como "gente", "meu Deus", por vezes associados a interjeições epistêmicas, que remontam a uma oralidade virtual, dado o contexto global fictivo.

Tais aspectos da dimensão epistêmica da AFic endossam as noções de fictividade geral, porém mapeiam pistas que contribuem para se categorizar algo como fictivo. O item (1) é de grande representatividade para se angariar o atributo da subjetividade para o fenômeno; o (2) ilustra a necessidade do valor epistêmico ancorado à dimensão discursiva, pois mesmo as expressões consagradas como fictivas (ex:: "A cerca vai do platô até o vale") podem ser tomadas como factivas, haja vista o próprio reconhecimento de Talmy (1996) de que uma parte de nossa cognição pode muito bem perceber a imagem de algo em movimento, percorrendo o caminho que vai do platô ao vale, sem tomarmos isso como algo irreal; o (3) emblematiza a necessidade de postulação de processos metafóricos e metonímicos subjacentes ao fenômeno, os quais certamente endossam a natureza incongruente da leitura fictiva em relação ao que ela referencia em termos de veridicalidade conceptualmente reificada, mas não de condições de verdade completamente externas; o (4) complementa o caráter subjetivista do fenômeno, a partir de escolhas próprias e adequadas à circunscrição de cada rotina de interação; o (5) diz respeito a uma particularidade de AFic, que é o escaneamento mental, em vez do movimento conceptual (AFac), embora ambos possam ter como base mecanismos de fictividade; o (6) adiciona ao conjunto de pistas o caráter generalizante da fictividade, visto que o vocativo apresenta granularidade de baixa 
resolução; sendo assim, a integração colostrucional interjectiva assume valor epistêmico. Ou seja: ambos, vocativo e interjeição, assumem valor mais abstrato.

Já a dimensão pragmática da AFic comporta tendências específicas para:

(1) no cenário de reportação (monológico e, por vezes, dialógico), AFics geralmente invocarem atos de fala fictivos, arregimentando proposições que aprioristicamente não teriam status epistêmico, mas se tomadas como promessa, planejamento, avaliação e apreciação, suscitam cenários de fictividade;

(2) no cenário reportado, o endereçado ser o próprio sujeito discursivo do cenário de reportação; já neste último cenário, o endereçado é ou são o(s) interlocutor(es), que assistem à digressão fictiva do falante e por vezes podem questionar o valor fictivo/factivo do juízo de valor emitido, expressando não somente dúvida acerca do que foi proferido, mas admiração ou espanto;

(3) no cenário de reportação, o usuário da AFic reivindicar face de amizade, aquela em que ele almeja ser socialmente incluído, na busca de solidariedade. Uma vez que a solidariedade é orientada em direção à face de amizade, expressa-se, em certa medida, uma determinada expectativa de empatia do(s) outro(s), postulando-se ênfase na afinação de pontos em comum;

(4) por vezes, haver incongruência dêitica entre a oração encaixada da AFic e o enquadre co-textual precedente, o que auxilia na leitura de fictividade da autocitação, mesmo em ambiente de reportação dialógico.

As características de (1) a (4) sustentam a dimensão pragmática da fictividade no âmbito da autocitação, considerando, a princípio, que a teoria da Linguística Cognitiva estuda a linguagem como fundamentada na intersubjetividade da interação social. Com isso, a dimensão epistêmica da fictividade está inapelavelmente ancorada à sua contraparte pragmática, em termos de emparelhamento global. Por isso, os itens (1) a (4) complementam interacionalmente os atributos fictivos do frame cognitivo de fictividade. Um dos aspectos é o fato de a AFic invocar atos de fala fictivos, de caráter epistêmico, cujo valor se alinha mais à contemplação de eventos passados ou futuros do que propriamente a ações presentes. Outro aspecto é a questão de o endereçado no cenário reportado ser o próprio falante da AFic no cenário de reportação. Isso remete a um debate interno exposto que figura como um juízo de valor destinado ao(s) participante(s) da cena de reportação, como se realmente houvesse ocorrido um debate prévio entre interlocutores. Com este ponto, pode-se preconizar a existência de frames interacionais fictivos, geralmente atrelados à reivindicação de face de amizade, visto que atos de fala digressivos ou reflexivos se alinham, por vezes, à busca de solidariedade e empatia. O arremate fictivo pode ainda ser representado pela incongruência que, em certas ocorrências, atinge o fenômeno da dêixis. E isso está na ordem 
da fictividade geral, em que ocorrências fictivas criam ambientes discrepantes em termos de referenciação.

A contar com as tendências apontadas, os frames cognitivos de fictividade atuam fortemente quando os frames interacionais de fictividade estão também em ação. O mesmo poderia talvez ser postulado para os frames cognitivos e interacionais de caráter factivo. Outras semioses podem contribuir para esse entendimento. Por exemplo, a epígrafe em arte digital (FCARTUNES, 2011) ilustra a inequívoca natureza semiológica e interativa da linguagem, ao mesmo tempo que circunscreve o fenômeno linguístico e sociocognitivo discutido: a autocitação fictiva e, por conseguinte, sua co-extensão factiva. Mesmo considerando todos os aspectos que tendem a delimitar uma e outra, a epígrafe pode ser interpretada fictiva ou factivamente. Considerando o interlocutor que gesticula e tem sua imagem desfocalizada e duplicada à esquerda, como se isto remetesse a um prévio debate interno, tendemos a postular, com base no título "So I said 'what the hell is that?'”, que ele faz uso de uma AFic. No entanto, o interlocutor de braços cruzados pode interpretar essa mesma autocitação como factiva. Desse modo, estaríamos diante de perspectivações conceptuais distintas, determinadas por sujeitos distintos, que podem representar conflitos cognitivos internos, porém não necessariamente conflitos de ordem interacional. "A fictividade é um fenômeno (in)questionável", "diria" o homem de braços cruzados.

ROCHA, L. F. M. Fictive Self-quotation in Brazilian and European Portuguese. Alfa, São Paulo, v.58, n.1, p.63-92, 2014.

- ABSTRACT: Studies about fictivity consider that certain linguistic expressions are only indirectly related to their meant referents; and that unreal scene is often presented by language users as means of mental access to the real scene. By overlapping cognitive and interactional frames, the fictive self-quotation phenomenon (ROCHA, 2004, 2006) is a discursive type of fictivity, by which conceptualisers pose a subjectifying assessing perspective to the direct speech in the first person. The main purpose of this paper is to analyse fictive self-quotation and its factive co-extension in oral corpora of European and Brazilian Portuguese, focusing on the construction "(I) said X-clause". As for the data, the C-ORAL-ROM Portuguese Corpus (BACELAR DO NASCIMENTO et al., 2005), the C-ORAL Brazilian corpus (RASO \& MELLO, 2010, 2012), and a database from the reality show Big Brother Brasil (2002) are used, all of which subjected to electronic data processing tools. The results present meaningful conceptual and diaphasic contrasts between the uses of "disse" and "falei" in the national varieties, since the verb "falar" is not often used to build a reported speech corresponding to mental space in the European Portuguese and that, from a constructional standpoint, certain interactional frames seem to favour fictive selfquotation more promptly.

- KEYWORDS: Self-quotation. Fictivity. Cognitive LinguistcS. Corpus LinguistcS. 


\section{REFERÊNCIAS}

AMIGOS DE JESUS. Falamos muito, dizemos pouco. Disponível em: <http:// amigosdejesus.com.br/site/?p=36>. Acesso em: 08 maio 2011.

BACELAR DO NASCIMENTO, M. F. et al. The Portuguese Corpus. In: CRESTI, E.; MONEGLIA, M. (Ed.). C-ORAL-ROM: integrated reference corpora of spoken romance languages. Amsterdam: John Benjamins, 2005. p.163-207.

BIG BROTHER BRASIL 1. Direção: José Bonifácio de Oliveira e Carlos Magalhães. Rio de Janeiro: Organizações Globo, 2002 (início do programa em 29 de janeiro - coleta do corpus entre 13 de março a 2 de abril). 47 fitas de vídeo (282 horas), VHS, son., color.

CORPUS CINTIL. Corpus internacional do português. Disponível em: <http:// cintil.ul.pt/>. Acesso em: 24 mar. 2011.

COSTA, A. L. da. Tenho dito. Disponível em: <http://vozpropria.blogspot.com/>. Acesso em: 07 maio 2011.

COSTA, S. R. Assim se interpreta assim. Veredas: revista de estudos linguísticos, Juiz de Fora, v.1, n.1, p.107-117, 1997.

CRESTI, E.; MONEGLIA, M. (Ed.). C-ORAL-ROM: integrated reference corpora for spoken romance languages. Amsterdam: John Benjamins, 2005.

DICIONÁRIO PRIBERAM DA LÍNGUA PORTUGUESA. 2010. Disponível em: <http://www.priberam.pt/dlpo/dlpo.aspx?pal=dizer>. Acesso em: 07 abr. 2011.

FCARTUNES. So I said "what the hell is that?" Disponivel em: <http://fcartunes. wordpress.com/>. Acesso em: 14 mar. 2011.

FRANCIS, E. J.; MICHAELIS, L. A. (Ed.). Mismatch:form-function incongruity and the architecture of grammar. Stanford: CSLI Publications, 2003.

GOLDBERG, A. Constructions: a construction grammar approach to argument structure. Chicago: The University of Chicago Press, 1995.

GRICE, H. P. Lógica e conversação. In: DASCAL, M. (Org.). Fundamentos metodológicos da linguistic. Campinas: Ed. da UNICAMP, 1982. v.4, p.81-103.

FALEI E DISSE... Disponível em: <http://jjdourado.blogspot.com/>. Acesso em: 07 maio 2011.

LANGACKER, R. W. Cognitive Grammar: a basic introduction. New York: Oxford University Press, 2008.

Virtual reality. Studies in the Linguistics Sciences, Urbana-Champaign, v.29, n.2, p.77-103, 1999. 
. Foundations of Cognitive Grammar: theoretical prerequisites. Stanford: Stanford University Press, 1987. v.1.

LÉVY, P. O que é virtual? Tradução de Paulo Neves. São Paulo: 34, 2009.

MURFY, D. Falei e disse: "A saúde entra pela boca". Disponível em: <http://www. fotolog.com/douglasmurfy/60040224>. Acesso em: 17 abr. 2011.

OFÍCIO DOS CHAVÕES. Disponível em:<http://oficiodoschavoes.blogspot.com/>. Acesso em: 07 abr. 2011.

PROJETO NURC. Projeto norma linguística urbana culta do Rio de Janeiro. Disponível em: <http://www.letras.ufrj.br/nurc-rj/>. Acesso em: 11 mar. 2011.

RASO, T.; MELLO, H. R. C-ORAL-BRASIL 1: corpus de referência do português brasileiro falado informal. Belo Horizonte: Ed. da UFMG, 2012.

The C-ORAL-BRASIL corpus. In: MONEGLIA, M.; PANUNZI, A. (Org.). Bootstrapping information from corpora in a crosslinguistic perspective. Florença: Firenzi University Press, 2010. v.1, p.193-213.

ROCHA, L. F. M. A fala silenciosa reportada: metáfora, metonímia e mesclagem. Linguística, Rio de Janeiro, v.2, n.1, p.23-38, jun. 2006.

A construção da mímesis no reality show: uma abordagem sociocognitivista para o discurso reportado. 2004. 254f. Tese (Doutorado em Linguística) - Faculdade de Letras, Universidade Federal do Rio de Janeiro, Rio de Janeiro, 2004.

SAEED, J. I. Semantics. Cambridge: Blackwell, 2003.

SANDERS, J.; REDEKER, G. Perspective and the representation of speech and thought in narrative discourse. In: FAUCONNIER, G.; SWEETSER, E. (Ed.). Spaces, worlds and grammar. Chicago; London: The University of Chicago Press, 1996. p.290-317.

SWEETSER, E. From Etymology to Pragmatics. Cambridge: Cambridge University Press, 1990.

STEFANOWITSCH, A.; GRIES, S. T. Channel and constructional meaning: a collostructional case study. In: KRISTIANSEN, G.; DIRVEN, R. (Ed.). Cognitive sociolinguistics: language variation, cultural models, social systems. Berlin: Mouton de Gruyter, 2008. p.129-152.

. Collostructions: investigating the interaction of words and constructions. International Journal of Corpus Linguistics, Amsterdam, v.8, n.2, p.209-243, 2003.

TALMY, L. Fictive motion in Language and "Ception". In: BLOOM, P.; PETERSON, M. A.; GARRETT, M. F. Language and Space. Cambridge: MIT Press, 1996. p.211276. 
UNIVERSIDADE DE FLORENÇA. LABLITA. Disponível em: <http://lablita.dit. unifi.it/>. Acesso em: 11 mar. 2011.

UNIVERSIDADE DE LISBOA. Centro de Linguística. CLUL. Disponível em: <http:// www.clul.ul.pt:. Acesso em: 11 mar. 2011.

UNIVERSIDADE FEDERAL DE MINAS GERAIS. C-ORAL BRASIL. Disponível em: <http://www.c-oral-brasil.org>. Acesso em: 11 mar. 2011.

WAUGH, L. R. et al. Multiple empirical approaches to a complex analysis of discourse. In: GONZALEZ-MAROUEZ, M. et al. (Ed.). Methods in cognitive linguistics. Amsterdam: John Benjamins, 2006. p.120-148.

Recebido em novembro de 2012.

Aprovado em janeiro de 2013. 